Portland State University

PDXScholar

Spring 2020

\title{
Friendship Projects Within Embargo: Peacemaking and Power Between US and Cuban Quakers 1987-2019
}

Jade Souza

Portland State University

Follow this and additional works at: https://pdxscholar.library.pdx.edu/honorstheses

Part of the International Relations Commons, and the Peace and Conflict Studies Commons Let us know how access to this document benefits you.

\section{Recommended Citation}

Souza, Jade, "Friendship Projects Within Embargo: Peacemaking and Power Between US and Cuban Quakers 1987-2019" (2020). University Honors Theses. Paper 922.

https://doi.org/10.15760/honors.944

This Thesis is brought to you for free and open access. It has been accepted for inclusion in University Honors Theses by an authorized administrator of PDXScholar. Please contact us if we can make this document more accessible: pdxscholar@pdx.edu. 
Friendship Projects Within Embargo:

Peacemaking and Power between US and Cuban Quakers 1987-2019

$$
\text { by }
$$

Jade Souza

An undergraduate honors thesis submitted in partial fulfillment of the

$$
\begin{aligned}
& \text { requirements for the degree of } \\
& \text { Bachelor of Arts } \\
& \text { in } \\
& \text { University Honors } \\
& \text { and } \\
& \text { Spanish Language and Literature }
\end{aligned}
$$

Thesis Adviser

Leopoldo Rodriguez, Ph.D.

Portland State University 


\begin{abstract}
This paper analyzes Quaker friendship projects between US and Cuban Quakers during the embargo period, with friendship construction being looked at as creative act within a contact zone. How are these intercultural friendships formed and sustained within religious communities of two countries in conflict? How do they relate to larger social dynamics such as intractable conflict and tourism? How do the friendships change the dynamics within these communities? In this paper two friendship projects are analyzed in terms of the strategies they employ to navigate the dynamics of conflict and social inequality between the two states.
\end{abstract}


Friendship Projects Within Embargo:

Peacemaking and Power between US and Cuban Quakers 1987-2019

The Cuban Quaker church descended from US Quaker missions that existed from 19001959. These missions were understood by the US Friends as evangelistic, pacifist, and humanitarian efforts, and yet in many ways they also mirrored the larger social dynamic of US imperialism and paved the way for US business expansion projects. In 1959, Cuba experienced their socialist revolution and the US missions were ended, followed by a long period with little contact between US Quakers and the surviving Cuban Quaker churches. In the 1980's, a new era of contact between the groups began. These relationships were informal relationships between individuals and churches, frequently described as friendships, and were sometimes formalized into sister-church-type relationships. Like their missionary predecessors, these friendships are seen as an alternative to the conflicted relationship between the two states.

The present-day projects are modeled as intercultural friendships. American Quakers do not oversee projects in Cuba as in previous years. The structure of Cuban society no longer allows for such projects. As a result of this, and the fact that Cuban society has in the preceding years elevated the level of public education to be equal or higher than Americans and for the levels of poverty to be greatly decreased, the two communities now relate on a more equal footing. Nonetheless, these relationships are constructed and navigated according to the political and social conditions of this time, including embargo, government surveillance, travel restrictions, and the influence of tourism. If the missionaries at the turn of the 20th century were naïve enough to believe themselves immune from such social forces, present generations have no such luxury. We know from extensive social science research that the power of things like systemic racism, militarized states, and tourism impact our most intimate of relationships. My research 
looks at Quaker friendship projects of today in terms of how they are understood and function in the Cuban Quaker church community. How are these intercultural friendships formed and sustained within communities from two countries in conflict? How do they relate to larger social dynamics such as intractable conflict and tourism? How do the friendships change the dynamics within these communities?

\section{Methods}

My methodology was a mix of literature review using multidisciplinary articles and books, and archival work in Cuba and in the United States.

On the Cuban side, I completed an internship at Instituto Cubano Cuáquero de Paz in Gibara where there has been a major archives project over the past few years of uploading historic minutes from the churches there. And I also looked at minutes and correspondence in the archives of local congregations.

Finally, I spent 3 months living in Cuba in the church and gathering documentation of some of the experiences of public church life there, and the ways in which intercultural relationships were talked about within the church. For example, I documented a workshop with participants from both countries to analyze the way they described these friendships, and analyzed the archives of one of these friendship projects and how they collaborated on the reclamation of a mission school building, which was transformed into a community center. My research reveals that current friendship projects between Quakers in the US and the United States are seen as authentic and mutually beneficial within the Cuban community, yet the larger social forces are an ever-present dynamic to be navigated. Viewing these relationships as an art of the contact zone (Pratt, 1991), I make observations about what strategies are being used currently to build 
and sustain the friendships, and develop recommendations for additional strategies.

\section{Limitations of research}

My research was limited by my own participation in intercultural friendships in the community. I visited Cuba for 3 months in 2016 as a Quaker and developed friendships with Cuban Quakers, especially those I home-stayed with. This experience opened doors for me in conducting this research as I already knew people and had developed trust with them, but just as easily interfered with any notion I might have otherwise had of being a neutral and objective observer. I was accompanied by my own desire to support these projects and the people involved in them and to protect my reputation in the Quaker community. Participants in the workshops and leaders who directed me in the archives may have also harbored concerns about their reputation or protection of the projects or people involved. This may have been influenced by my position as an American with influence in the US Quaker community, my relationship to host families within the meeting, or other concerns including the common occurrence of government surveillance. In the context of the workshop and other face-to-face work as well as in archival work, I did my best to be transparent, honest, an open to whatever truth was revealed. There were times where my research led me to learn uncomfortable or painful truths, and I have attempted to treat them equally as the more positive findings. I have chosen to remove identifying information from the research.

Unfortunately, timing constraints in the planning of this research did not allow for IRB process to be completed, so while I had originally intended to use personal interviews in 
the research, I was not able to rely on these for the thesis. One-on-one interviews would reveal other dimensions of these friendships that are difficult to glean from archives and literature, and would provide the opportunity to ask questions-for example, to ask about the meaning behind language used to describe the friendships, etc.

Other limits of my research include language barriers. I read or translated a number of sources from the Spanish language sources myself, including the workshop. As a non-native speaker, there may be times that I missed nuances or misconstrued meanings that limited my understandings.

\section{Literature Review}

I reviewed literature from a number of disciplines, looking at how social forces affect relationships from the intimate to the political, including Cuban history of religion and its ties to Cuban identity. I explored history as a discipline central to Cuban identity, looking at this history from several perspectives.

In Between God and the Party, Canadian professor of Latin-American studies John M. Kirk gives a general overview of religious-political relations in Cuba from the colonial period until the book's publication in 1989, a period in which Cuban religious life was being reinvigorated through the softening of relations between religion and the state in Cuba, and the sensational release of Fidel and Religion, which sold 1.3 million copies in Cuba. Part one of Kirk's book focuses on the pre-1959 history of the Cuban church (both Catholic and protestant) and part two explores the revolutionary period until publication. He tracks how major events affected the political rhetoric and positioning of church leadership, as well as the religious language and posturing of political leaders through post-revolutionary decades that included both periods of 
tension and conflict and others of peaceful coexistence.

(Kirk, 1989)

In Cuba: Religion and Civil Society, Margaret Crahan looks at Cuban religion's relationship to civil society including the unique role of popular and Afro-Cuban religions in Cuba and how the revolution has changed its relationship to religion over time. She argues that while Cubans are deeply animated and united by religious faith, religion has failed to become a strong mobilizing force within Cuban civil society. (Crahan, n.d.)

In The Structure of Cuban History, Louis Pérez gives a comprehensive and sweeping history of Cuba to build the argument of how meaning, purpose, and identity are constructed from the events of past within Cuban society. This phenomenon of Cuban memory both contributed to and became an integral part of the $20^{\text {th }}$ century revolution. In his perspective on the role of religion, Pérez explores how events of history made Cubans wary of institutional religion. Both Catholic and Protestant churches within Cuba have generally positioned themselves in opposition to the sense of Cuban sovereignty that he describes as central to the Cuban identity. He also explores issues of identity such as the historical construction of lo cubano, or "authentic Cubanness", which was also a concern of the Quaker missions. (Perez, 2013)

These history articles and books gave the broader context and philosophical underpinning for my interpretation of history from within Quaker archives, both in the United States and in Cuba. For understanding Quaker events, I used the 1948 American Board of Missions publication Religious Life on our Missions Fields, which gave its own sweeping history of religion in Cuba dating back to an account of Taíno chief Hatüey’s proud resistance and martyrdom to the cruelty of Spanish missionaries, and through the Quaker missions projects until the date of publication. I also relied extensively on American Quaker Hiram Hilty's history 
Friends in Cuba, as well as his biography of Zenas Martin. Friends in Cuba gives a history of Quakers in Cuba using primary sources as well as interviews conducted in the 1960's and explores the Cuban Quaker experience of and reaction to the early revolutionary period. I also reviewed Karen Leimdorfer's dissertation Cultural Imperialism or Cultural Encounters where she looks at the Cuban Quaker missions and evaluates if they can truly represent a cultural encounter or if they are cultural imperialism. She argues that the projects cannot be considered true cultural encounters because of several factors which confuse or undermine this objective: 1 . Cultural imperialism is evidenced by the unwillingness of missionaries to release the projects to independence, mirroring the political dynamic of the state actors, 2 . The schools and churches started by the missionaries attempted a confusing and conflicted missions of promoting Cuban independence and authentic "Cubanness", while also imposing American cultural and religious values in overt and more indirect ways, 3 . The projects were largely funded by United Fruit Company which had an ulterior motive in US business expansionism. Leimdorfer describes systemic inequality the Cuban missions, citing that missionaries recruited church members from the poor and working classes, while recruiting pupils for the schools from the upper classes. The latter they regarded as future national leaders, and some were-- Fulgencio Batista attended the Quaker school in Banes. Unlike the Catholic church, the Quakers trained and ordained Cubans, not just foreigners--both men and women-- for the ministry; but they did not give complete governance of the churches and schools to the Cubans.

These contradictions within the mission came to a head when the missionaries were clearly opposed the 1959 revolution which ultimately ended their missions and schools, while according to Hilty, a majority of Cubans in the Quaker churches supported the revolution both in its early nationalistic mission and its later socialist one. (Hilty, 1977; Leimdorfer, 2008) 
Literature from the field of history reveals that themes of authenticity, mutuality, and equality have been potent within these relationships. The navigation of these matters-- within Cuban religion, within the relationship between politics and religion, throughout Cuban history-is central to the Cuban identity.

In the contemporary period, I looked at Geographies of Friendships and Bridging Cultures, considering various ways friendships are understood within the field of geography and intercultural communication. These articles examine how friendships are constructed under various social conditions including cultural exchanges, and how geographies of mobility and transnationalism impact friendship. (Bunnell et al., 2012; Lee, 2006)

At the micro level, I looked at Valerio Simoni's ethnography article about how such dynamics of authenticity, mutuality and other friendship qualities are performed and navigated on the intimate level comparing perspectives on romantic and sexual relationships and friendships between tourists and Cuban jineteros. Primarily, this ethnography focuses on whether the desire for financial benefit is a threat to the authenticity of romantic love in these relationships, as well as how the inequalities and lack of autonomy impact the perception of authentic love. Simoni first questions what biases may be present in this idea of purity or authenticity of the relationship, but finds that the jineteros too, are concerned about these questions. Ultimately argues that both authenticity and inauthenticity, and a sort of struggle for mutuality can be in a dynamic interplay in these relationships.

This conclusion is echoed in In the Arts of the Contact Zone, which argues that postcolonial spaces such as Cuba in their conflicted nature--or as articulated by Quaker missionary May Jones, the "ridiculous blending of the old and new"(Leimdorfer, 2008)--- is a creative space where new forms of literature can emerge. The theory of the contact zone was developed by 
Mary Louise Pratt to identify the conditions that give rise to new forms of literary expression. The arts of the contact zone have unique power to creatively respond to, engage with, and subvert traditional narratives that reflect the hegemony and/or more homogenous societies. A common theme in arts of the contact zone is authenticity, and these arts are able to "move into and out of rhetorics of authenticity" (Pratt, 1991). What does this mean for friendships in the contact zone? Within the contact zone there is possibility of exploitation, deception, and betrayal; but also of authentic expressions of selfhood, creative strategies of solidarity, and struggle for mutuality, as observed by Simoni. (Simoni, 2016) I do not conclude, as Leimdorfer does that the objective of cultural exchange was completely obfuscated by the involvement of cultural imperialism. I think that the writings of the missionaries as well as the history as described in Cuban archives belie a more complicated mixture of conflicted perceptions, motivations, successes, and failures such as those observed by Simoni and framed as arts of the contact zone by Pratt. The Quaker missionaries struggled for and against Cuban independence in different moments. They experienced conflict within their own group about questions of equality and mutuality of the missions, and the involvement of US business interests. (American Friends Board of Missions, 1948; Hilty, 1970) Some US promoters of the missions became supporters of the revolution. (Hilty, 1977) After the revolution, the Cuban Quakers were leaders in developing new contact zone theologies that rose from the Cuban ecumenical movement.(Hilty, 1977; Santos, n.d.)

Authenticity, autonomy and self-determination, equality, and mutuality emerge as a strong themes throughout all the literature, as they have throughout Cuba's history. These are issues central to the Cuban identity, to the contact zone, to friendships generally, intercultural friendships more specifically, and to Quaker theology since its inception. In my analysis of two 
friendship projects in Cuba, I look for where these themes emerge, as well as concrete ways that these intercultural friendships are constructed and sustained over time, considering ways that they may now be creatively navigating the contact zone, or ways that they may in the future.

\section{Historical Context}

\section{Missionary period (1900-1959)}

The missions were started in 1900, fueled by Quaker pacifist convictions and social concern for Cuba after the US-Spanish war. The projects were seen by missionaries as promoting peaceful mutual resolution of national conflict and addressing social inequality and other social problems in Cuba. Despite these noble aims, the missionaries held other, conflicting attitudes and actions. For example, while they talked of creating a Cuban Quakerism, they resisted giving oversight of the projects over to the Cubans, mirroring the larger political dynamic between the two states. They received funding from the United Fruit Company for the missions, positioning themselves in partnership with a US company which saw the Quaker religious movement as useful to its expansionist objectives. Although they took actions for equality, some missionaries also harbored racist perspectives about Cubans as were prevalent within the culture of US evangelical Protestantism. (Hilty, 1970, 1977; Leimdorfer, 2008)

Of United Fruit Company, founding Quaker missionary Zenas Martin wrote to the American Board of Missions with a surprising degree of awareness and critique of the company owned by his friend and financier Captain Lorenzo Baker: "[As the United Fruit Company] increases in wealth and power [it] may increase in oppression of the people and methods of business that will 
be in opposition to our teachings. ...I look upon the large, soulless corporations of the US, that are being organised in Cuba, as one of the great difficulties in the way of progress of the people, both in temporal and spiritual things. I fear Cuba is not yet free.” (Leimdorfer, 2008, p.73) It is worth noting that this quote also suggests something about the mentality among Quaker missionaries of the time. Though it had been many years since their original resistance to stateimposed religion and hierarchical church polities, Quakers of this era, now better known for successful business ventures, still viewed themselves as a "peculiar people" set apart from both worldly projects and other denominations. Zenas Martin was a business man himself, and despite his cautionary words in this letter, was not at all opposed to mixing business with churchplanting. He eventually went on to develop his own sugar business in Cuba, raising controversy with the American Board of Missions, which ultimately prohibited Quaker missionaries from being involved in business ventures in their countries of operation. (American Friends Board of Missions, 1948; Hilty, 1970).

Revolutionary changes (1960-1987)

All remaining missions were laid down along with the withdrawal of other US projects after the 1959 revolution. The churches continued to operate, but were greatly diminished in size in the coming years. With the Cuban state's partnership with the Soviet Union it became officially atheist, Cuban religion was forced somewhat underground. The older generations and middle class members generally opposed the revolution, and many immigrated, while many of the younger Quakers and those working-class areas in Oriente supported the revolution, and Marxism and atheism became widespread. The Quaker churches were reduced to a fraction of 
their size. Because of these changes, and the severe restrictions on international involvement placed on Cubans, there was little contact between Friends in Cuba and international Friends groups in the coming years.(Hilty, 1977)

Renewed projects of friendship (1987-present)

In the 1980's, several Cuban Quakers were able to attend international Quaker conferences. Because of this, and because of new humanitarian needs in Cuba after the fall of the Soviety Union, international awareness of the existence of Cuban Friends rose. US and British Friends began organizing visits, and some of these developed into ongoing relationships. It was during this time that the Puente de Amor, one of the friendship projects that is still in existence, began. These contacts increased over the coming decade with visits and work brigades from Friends United Meeting, New England Yearly Meeting of Friends, George School, George Fox College, Guilford College, Wilmington Yearly Meeting of Friends, and other Quaker groups. Wilmington and New England Yearly Meeting were formalized into friendship projects.

\section{Social Context}

Cuba was historically an important contested site of colonialism and imperialism. Cuba's geography locates it as a site of importance for empires struggling for power--as a trade route, including for the slave trade, and important site for military control of the region. These historical conditions and the contemporary conditions which they nurtured place it in what is known as a contact zone. Contact zones are social spaces where cultures "meet, clash, and grapple with each other, often in contexts of highly asymmetrical relations of power such as colonialism, slavery, or their aftermaths as they are lived out in many 
parts of the world today."(Pratt, 1991)

The history of the Friends missions prompts questions about the challenges and even feasibility of creating authentic intercultural projects within fraught social and political contexts. The projects involving US and Cuban Quakers today are focused on intercultural friendship, as opposed to humanitarian or evangelistic projects. Can such projects be more successful at resisting the larger social forces at play and sustaining themselves through the volatile dynamics of the contact zone?

Friendship is generally understood in terms of sincerity, mutuality, trust, transparency, and unconditionality. We measure our friendships and distinguish them from other types of relationships by our relative perception of these qualities. These qualities become difficult to build in the dynamic, high-conflict, and complicated social and political space of the contact zone when there are inequalities present.

Friendships are constructed and develop friendship attributes through activities that include notably mutual support, rituals and joint activities, exploring similarities and differences, and how conflict is approached and managed. (Lee, 2006) To the degree that building friendships is also a creative process, we could consider such relationships another art of the contact zone. Just as literary forms emerge from the contact zone which subvert and complicate the dominant paradigm, so intercultural friendships have potential to do so. We know that inequalities can create barriers to authentic friendship, and we know that social forces such as interstate conflict, racism conscious or unconscious, and business interests, influence human relationships at the most intimate level. In the case of friendships between Cubans and US citizens, for example, the construction of friendships is negotiated within limitations imposed by each state, the surrounding conflict culture, and the literal policing of these activities by both states. Other 
structural impacts on friendship include the dynamic of tourism, and the structural inequality between the two communities.

Awareness of the power of these dynamics and the pressures they place on the friendship is one important aspect of preserving the integrity of the friendship qualities, but additionally, developing creative strategies that subvert the dominant dynamics is a necessary aspect of these friendships.

If Quaker missionaries to Cuba demonstrated some level of awareness of these dynamics in their own time, they failed to develop robust strategies to subvert them. Their models were similar to the dominant model, even if attitudes or intent were indeed (as they believed) different. Ultimately, the relationships between the communities as constructed were not sustainable through either the American depression or the Cuban revolutionary changes.

\section{Puente de Amor: Cuba Yearly Meeting and New England Yearly Meeting}

In February of 2020, I attended a workshop during the annual meeting of members of Cuba Yearly Meeting on the subject of Puente de Amor. As a participant-observer, this meeting was audio recorded and then transcribed and translated to English. 17 participants were present, with a small number 3-4 from the United States and the majority from Cuba. The workshop was a brainstorm meeting about strengthening the Puente de Amor, one of the formalized friendship projects between Cuba Yearly Meeting and New England Yearly Meeting.

Puente de Amor was started in 1993, making it the longest standing of the friendship projects. In recent years two policy changes from the United States have affected the project. First, the US embassy in Havana, Cuba, opened in 2015, was closed following neurological problems in US 
embassy employees of unknown origin in 2017. Without a Unites States embassy in Cuba, Cubans who wish to travel have to obtain permission to go to a foreign country for their visa interview making the process much more expensive and cumbersome. For many this barrier makes travel no longer a possibility.

Second, the licenses permitting Americans to travel to Cuba were further restricted and modes of travel restricted due to changing US foreign policy under president Donald Trump. While the restrictions still permitted religious license used by the majority of Quakers visiting Cuba, the high-profile nature of the increasing restrictions had a cooling effect on travel of Americans, and increasing economic difficulties in Cuba combined with loss of the embassy made it difficult or impossible for Cubans to travel to New England.

As a result of these two situations, visits, which have been a cornerstone of this friendship project, have been limited. In 2018, New England Yearly Meeting and Cuba Yearly Meeting issued an open, bilingual letter officially opposing travel restrictions as well as the embargo, addressing both Cuban and United States governments. (Fig. 1) In this letter they argue that travel, visits, and Puente de Amor are as essential to their Quaker religious practice as prayer, and that they will legally challenge any threat to this religious right, including the denial of visas. This action is significant in several respects: 1) It expands the contact zone friendship's sphere of influence beyond the faith communities to involve the state actors, and 2) By sending a joint letter to both governments, it represents a subversion of roles and identities consistent with an art of the contact zone as well as contact zone arts of critique, collaboration, bilingualism, denunciation, (Pratt, 1991) 3) It elevates the shared language and rituals that are used to construct the friendship to a public and historic document, and 4) It represents a shared act of resistance to the intractable state conflict opposed by Quakers, a new shared ritual in the 
friendship. Facilitators asked participants to reflect on how Puente de Amor has affected their lives, and then to consider how links can be strengthened in the future given these changing realities. The interest group drew seventeen participants, while other workshops only drew 5-6, demonstrating tremendous interest in this project. The group met at $9 \mathrm{pm}$, following a full day of business reports and committee meetings in Quaker business process.

The affect of the room was energized and participants were enthusiastic to share. The workshop went over time and was cut short with a plan to continue it the following night, but this did not occur. Participants mentioned mutuality of the project frequently, including statements about the mutual emotional and spiritual benefits and benefits of the cultural exchange, with emphasis placed on the equal participation and equal sharing of benefits between the meeting. Statements of mutuality included statements such as, "It seems to me that the major beneficiaries of the Puente is equally the Cubans as the Americans."

The most common theme in the responses were statements of unity. Unity was often contrasted with cultural, geographical or political differences between the groups, or with challenges to the friendship such as changing travel restrictions. Unity was talked about in spiritual terms such as being "one in the Spirit" or "united in the love of God", contrasted with worldly situations. This is consistent with language in traditional Quaker writings and teachings.

Many times the commentary began with mention of challenges, differences, or specifics, and followed the pattern of returning to the emphasis on shared spiritual language towards the end. While this was instructive as far as the friendship projects well-established patterns of shared language and religious practices, it was also at times difficult to analyze the commentary which came in the form of short sermons or testimonies for information about specific strategies. Take this example, which typifies the of the flow of commentary from referring to worldly 
matters or specific details about the to honing in on a spiritual message:

"I'm certain that throughout the years the Puente, more than a bridge has been a channel of blessings for both peoples. Peoples that throughout history each one with their respective geographies and politics have had their own debates. The Puente has been a perfect link to unite Quakers of the United States and Cuban Quakers. What comes to mind is to make a quick comparison in reference to music, something that I play a lot personally. The main concept of music is the art of combining well the sounds and the timing and the Puente has been a bit like that. The Puente has taught us how to combine ourselves first in the love of Christ, love of God and then how to love brothers as people. It has taught us to come together and learn each one about the other, to take one anothers' hands and walk in the path of justice and love that is our Lord Jesus."

Some specific challenges to the projects were brought up including political differences, travel restrictions, and language and cultural barriers. Challenges to the friendship were talked about in terms of something to be overcome using prayer, or spiritual values such as "having faith", "with love" or statements that God would protect the projects. There were no concrete actions mentioned to overcome challenges. Authenticity of the friendships was expressed in statements such as "real friends" "sister in faith", or describing actions such as communicating daily with a friend, or communicating on significant days such as birthdays.

Cultural benefits were referred to 11 times in the reflections, with comments for example about “opening world", or about learning and sharing culture. One participant commented on the importance of this for Cubans who had been for a while "cut off from the world". The project was described frequently in terms of its spiritual benefits, and secondly for its 
emotional benefits. Spiritual benefits were talked about using language such as "this has been a blessing", identifying God's role or presence in the project, that God will sustain the project, or making statements such as "this friendship is eternal".

Also included were comments about spiritual identity: Participants strengthening of the Quaker identity as being a benefit to the Cubans, that they learned more about this identity or identified more deeply with it through the friendship.

Notably, the word privilege was used five times during the reflections, and each time in reference to the opportunity to travel to the United States, demonstrating some ability to discuss inequalities within the mixed group.

Specific friendship building activities that were talked about included communication and sharing of spiritual literature through What's App, and frequent mentions of home stays. (Puente de Amor Workshop, Cuba Annual Sessions, 2020)

\section{Puerto Padre-Wilmington friendship}

In 1902, Puerto Padre was recommended by Zenas Martin to Wilmington Yearly Meeting (Ohio) as a site for their own mission field, to be administered by the American Board of Missions. The city's location near the plantations of American Sugar Company was part of the criteria for selecting the site. Puerto Padre went on to be the site of a Quaker school and the home of the longest active US missionary Emma Martinez, who arrived in Cuba with start of the mission in Gibara in 1900, and died in Puerto Padre in 1946 (Hilty, 1977).

The Puerto Padre friendship was renewed when a descendent of the missionary with a historical interest visited Puerto Padre and developed personal connections there. These individual friendships developed into shared interest over the former school which had been in a state of 
disrepair and disuse under the Cuban government since 1960. Cuba Yearly Meeting had written letters throughout the years asking for the reclamation of their building without expectation of a response. When the building was finally returned, Puerto Padre meeting had dreams of renovating it and turning it into a community center, and this became a collaboration between the two meetings, with Puerto Padre directing the project, and Wilmington fundraising.

The project energized both communities, and correspondence was mutual, involving cultural sharing, documentation of shared history, and personal sharing, for example, introducing family members. Notably, Wilmington's fundraising was not simply a philanthropic drive which might maintain distance between the groups, but rather involved shared rituals and cultural exchanges which strengthened the bond of the communities. For example, they hosted a Cuban pork sandwich fundraiser and a coin-bank project that focused on children's participation. Work brigades came to Cuba, often staying in homes.

Figure 2. A letter sent from Cuba to Wilmington Yearly Meeting in which church leader Jorge Pena shares information about the importance of Cuban historical figure Jose Marti. Examples of cultural sharing from the Cuban to Americans points to growth in the mutuality of the friendship model since the missionary period, where despite the partnerships, examples of Cuban culture influence on American Quaker churches was minimal. Now we see examples such as this one, where the martyr from the first Cuban revolution is invoked in the collaboration of the friendship project. While economic inequality is ever-present and evidenced by American Quaker funding of Cuban projects, two-way cultural sharing is an important aspect of mutuality in these projects, here evidenced by bilingual letter sharing and sharing of cultural artifacts.

Figure 3. Another letter from Jorge Pena to American church leaders. The process of making requests for correspondence to be translated by bilingual community members and shared 
between monolingual ones is another representation of the contact zone arts of collaboration and bilingualism. Photos are personal and emphasize the collaboration of equals. All correspondence from the project was archived by a member in the United States in the manner of a scrapbook and presented as a gift to Puerto Padre. This friendship ritual is one of curating a new shared history.

Figure 4. Wilmington's church in Cuba, Ohio share documentation of their childrens' coinsaving fundraiser, pictures of their buildings, and share greetings in Spanish.

Figure 5. Jorge Pena writes his take on the reclamation of the building, another act of documenting and archiving a new shared history together. He invokes the past shared history, including the missionaries.

These examples came from an archive which documented this friendship over the course of many years. We see the themes of authenticity as photos of people's personal lives are shared, as well as in moments as individuals contribute perspectives related to politics, history, and culture. Bilingualism and language flexibility allows participants to access the projects and connect in an authentic and mutual way. Mutuality is supported by the equal exchange of correspondence, by the shared narrative of a collaboration and documentation of the project as such, by shared spiritual language, and the collaborative documentation of a new shared history.

\section{Findings and Future of the Friendships}

Friendship projects between US and Cuban Quakers continue to struggle creatively for mutuality within the context of inequalities, intractible conflict, embargo and other powerful social and 
political forces. The relationships are regarded as beneficial and necessary by both communities.(Puente de Amor Workshop, Cuba Annual Sessions, 2020)

The current conditions of US-Cuban relations have presented challenges to these friendship projects, but the communities have taken creative actions to build and sustain the friendships in the face of these challenges, at times using them as a point of resistance against the interstate conflict. They have used shared spiritual language and rituals as well as shared history to strengthen the friendships. They have nurtured bilingualism, mutual cultural sharing, conflict resolution strategies, collaborations, denunciation and other arts of the contact zone to creatively navigate and resist social forces that threaten the authenticity, mutuality, equality and selfdetermination within the friendships. Inequalities are talked about within the friendships, and some actions have been introduced to mitigate the effect of these- - such as ensuring that opportunities for travel are shared among Cuban Friends through a rotation system, or placing limitations on personal remittances between individuals. Whether these are effective in mitigating inequality is a matter for further research. The projects would do well to continue in their evaluation of these strategies and objectives, centering Cuban perspectives from a broad section of the community in evaluation processes as much as possible.

As changes in the conflict zone are inevitable, the friendship projects will need to be prepared to maintain this flexibility and creativity in how they sustain the friendships the face of changing conditions.

If the history of the Quaker missions' messy life and death is any teacher, this will necessarily and primarily include an attention to mitigating inequalities present in the friendships, or more specifically, taking actions to increase the power, authority, and autonomy of Cuban Friends to express, participate in, seek benefit from, and determine the course of these friendships as equals 
despite structural inequalities that may be present.

If the embargo is lifted, the embargo period may prove to be the least complicated time for Quakers in terms of navigating these complexities. US tourism and business involvement in Cuba will surely return to its pre-1959 vigor, and with it dynamics of oppression and strategies of exploitation will be introduced to the landscape of the friendships. Quakers are in general careful to maintain neutrality in international politics, generally interfering in other nations only with questions of war. This was true of the Quaker missionaries, who weighed in with Cuba's governance only to oppose violence. Yet although cognizant of the dangers presented to their missions, they proceeded to align themselves with powerful business interests. If the friendship projects are to maintain their authenticity, integrity, and mutuality as cultural exchange projects, US Quakers should be cautioned that involvement in foreign business interests inherently represents political participation.

Regardless of whether the embargo is lifted, political changes are likely if not inevitable. Throughout these changes, participants in friendship projects may need to employ new strategies to maintain the friendships. 


\section{Works Cited}

American Friends Board of Missions. (1948). Religious life on our mission fields. American Friends Board of Missions.

Bunnell, T., Yea, S., Peake, L., Skelton, T., \& Smith, M. (2012). Geographies of friendships. Progress in Human Geography, 36(4), 490-507. https://doi.org/10.1177/0309132511426606

Crahan, M. E. (n.d.). Cuba: Religion and Civil Society. 24.

Hilty, H. H. (1970). Zenas L. Martin, Quaker Pioneer in Cuba. Quaker History, 59(2), 81-97. https://doi.org/10.1353/qkh.1970.0003

Hilty, H. H. (1977). Friends in Cuba. Friends United Press.

Kirk, J. M. (1989). Between God and the party: Religion and politics in revolutionary Cuba. University of South Florida Press.

Lee, P.-W. (2006). Bridging Cultures: Understanding the Construction of Relational Identity in Intercultural Friendship. Journal of Intercultural Communication Research, 35(1), 3-22. https://doi.org/10.1080/17475740600739156

Leimdorfer, K. (2008). Cultural Imperialism or Cultural Encounters. VDM Verlag Dr. Mueller e.K.

Perez, L. A. (2013). The Structure of Cuban History: Meanings and Purpose of the Past (1 edition). The University of North Carolina Press.

Pratt, M. L. (1991). Arts of the Contact Zone. Profession, 33-40. JSTOR.

Puente de Amor workshop, Cuba Annual Sessions. (2020, February). 
Santos, H. (n.d.). Evangelismo presente e futuro (p. 4) [Unpublished report]. Instituto Cuaqero Cubano de Paz. 


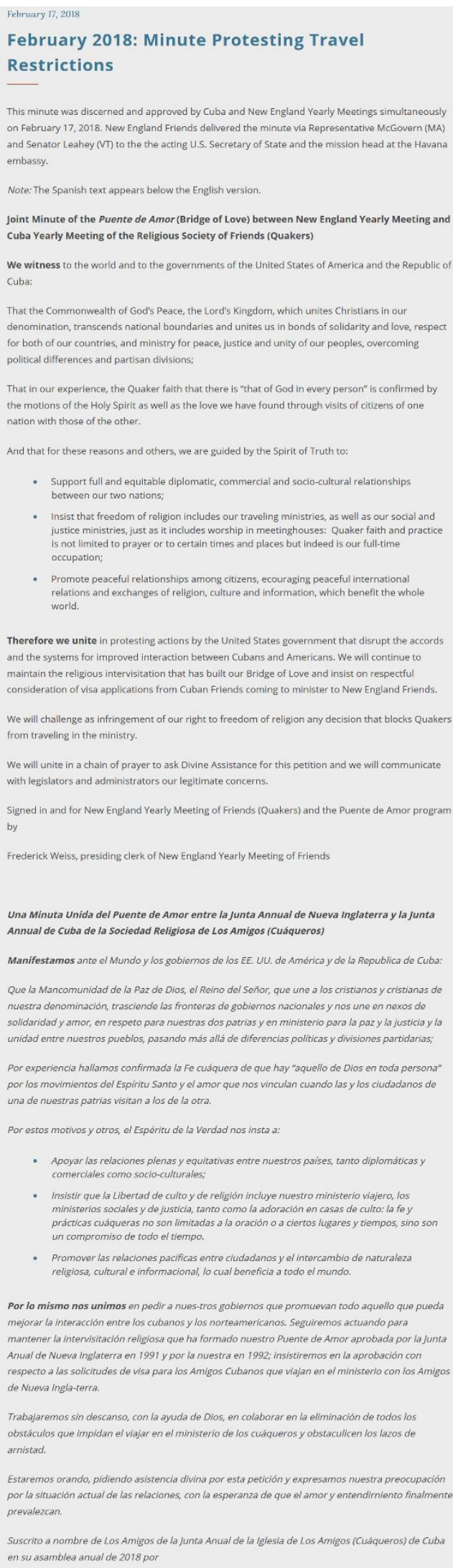

Trabajaremos sin descanso, con la ayuda de Dios, en colaborar en la eliminación de todos los obstáculos que impidan el viajar en el ministerio de los cuáqueros y obstaculicen los lazos de arnistad.

Estaremos orando, pidiendo asistencia divina por esta petición y expresamos nuestra preocupación por la situación actual de las relaciones, con la esperanza de que el amor y entendirniento finalmente prevalezcan.

Suscrito a nombre de Los Amigos de la junta Anual de la Iglesla de Los Amigos (Cuáqueros) de Cuba en su asamblea anual de 2018 por

Figure 1. 
Figure 2.

\section{Greetings}

Greetings from Jorge Luis Pena, Clerk of Puerto Padre Meeting and Clerk of Cuba Yearly Meeting, to Wilmington Yearly Meeting

Jose Marti, the National poet of Cuba, said "climbing mountains makes men Into brothers".

Working together on the same project, regardless of barriers, has created a strong connection between our two Monthly Meetings just as Eva Terrell had with the people of Puerto Padre over a hundred years ago when she served as Missionary at the Quaker Church and School. The community sees the value of the work being accomplished. We are flooded with enthusiasm in this walk together.

We have made dry bones and ruinous bones come to life in front of a village that saw the Wilmington School flourish and nearly die. Let us not let this relationship dim but keep building the bridge that connects us

God bless our bridge of love and Christian faith.

\section{anges Saludos}

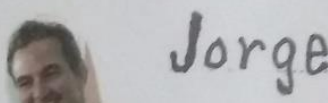

José Marti el poeta national of Cuba dijó que subir lomas hermama hombres. Trabajar juntos en un mismo proyecto sin importar barreras ha creadó ligaduras entre nuestros grupos como si hubiérmos logrado hacer calidos y cercanos aquellos anos fundacionales en que Eva Terrell viviá entre los cubamos. Hay mucho de ustedes en esta etapa que vive nuestra comunidad. Much hay de sus niños que ofrecen desde la pureza de sus manos. Estamos impregnados del entusiasmo de ustedes en este caminar juntos que emprendemos. Hemos logrado que esos huesos secos y ruinosos cobren vida delante de un pueblo que vió el colegio Wilmington florecer y casi morir. No dejemos palidecer esta relación que es como un puente sobre toda diferencia.

Dios bendiga mucho nuestros vinculos de un amor that que edifice.

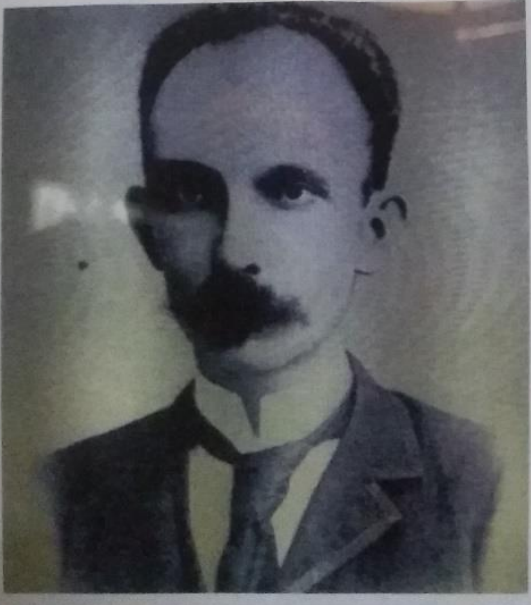

José was crucial to the success for the cause Of Cuban independence against Spain. He died In military action.

José fue crucial para el exito de la causa de la Independencia cubana contra Epana. Murio' En acción militar 
Figure 3.

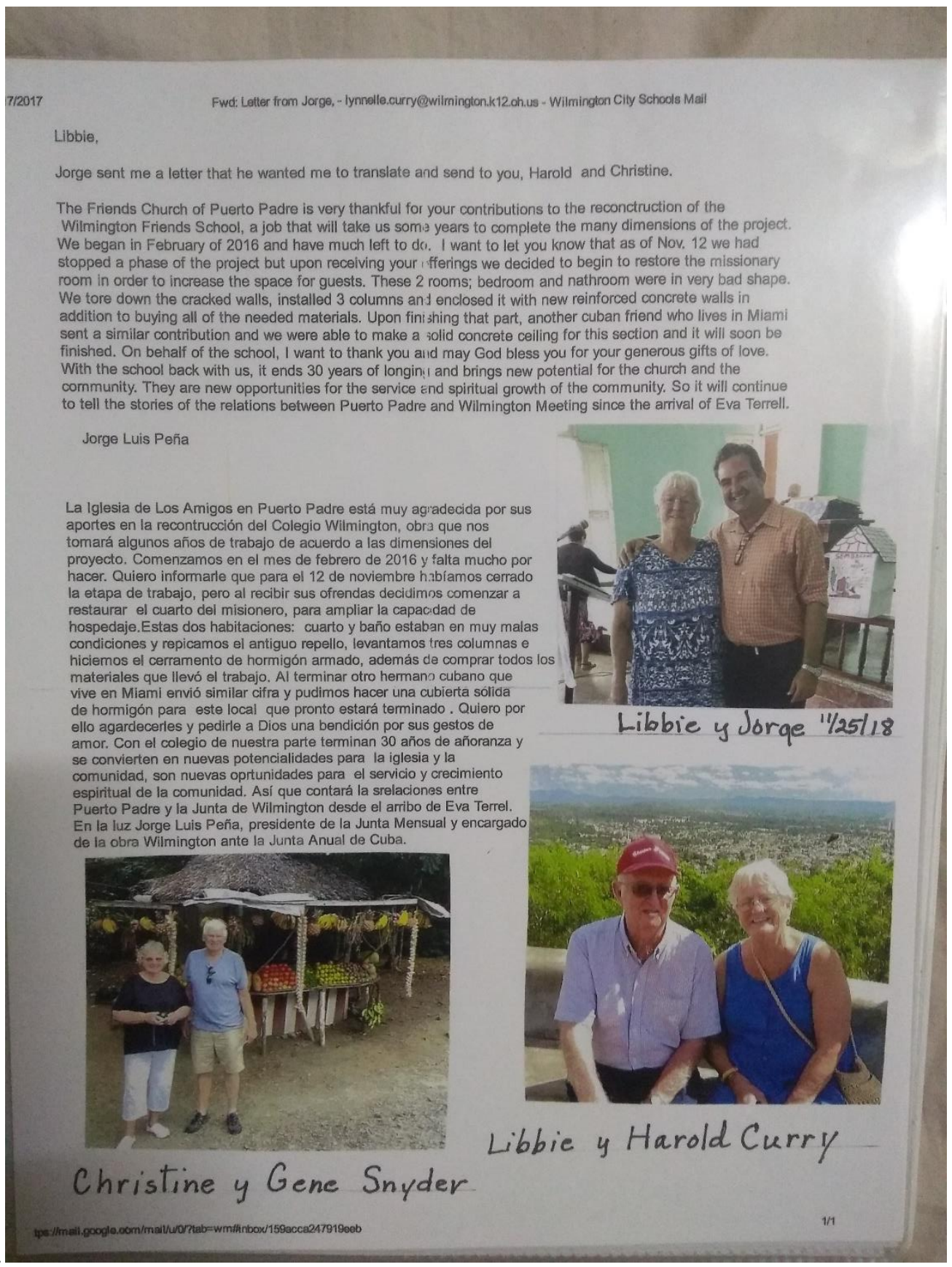


Figure 4.

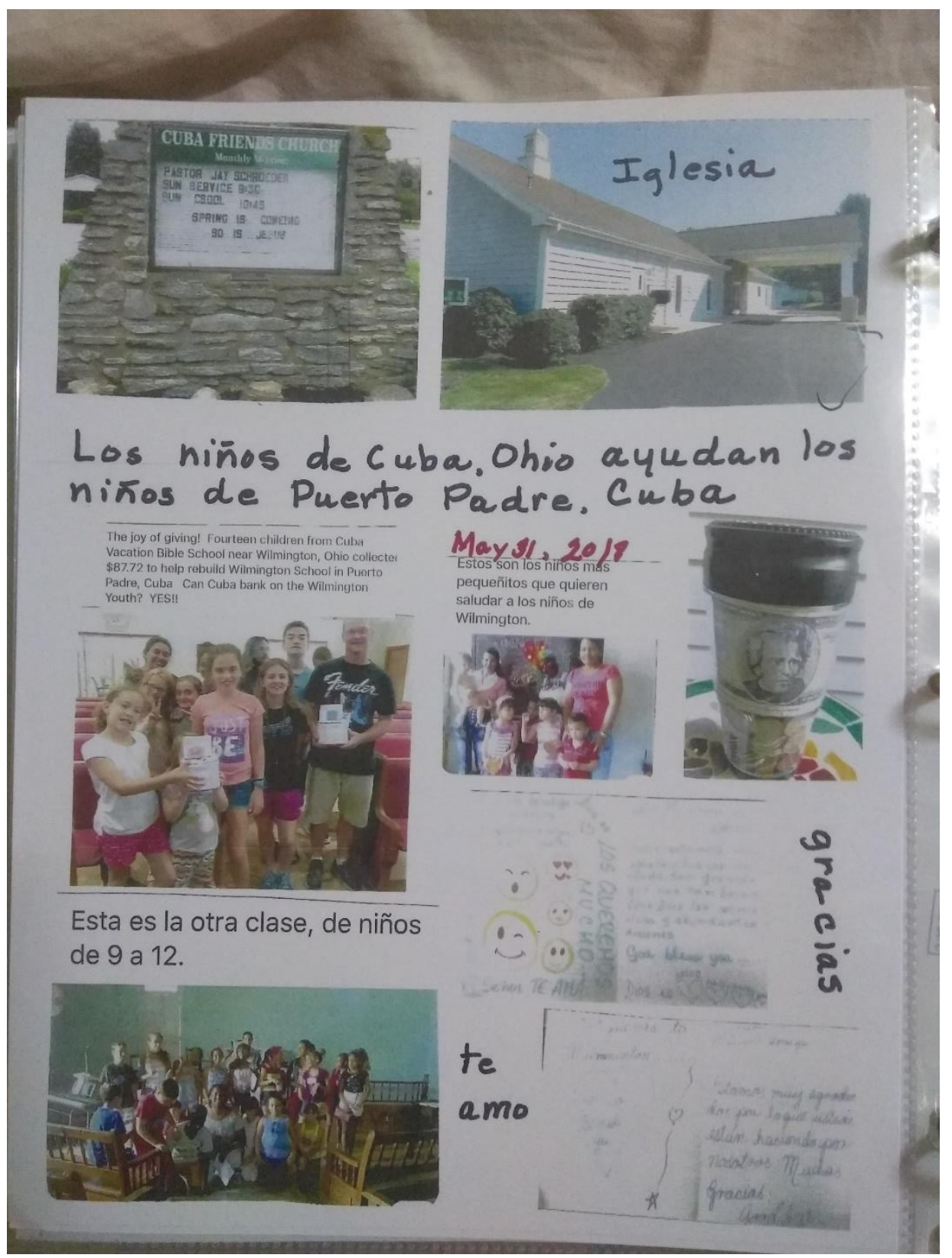


Figure 5.

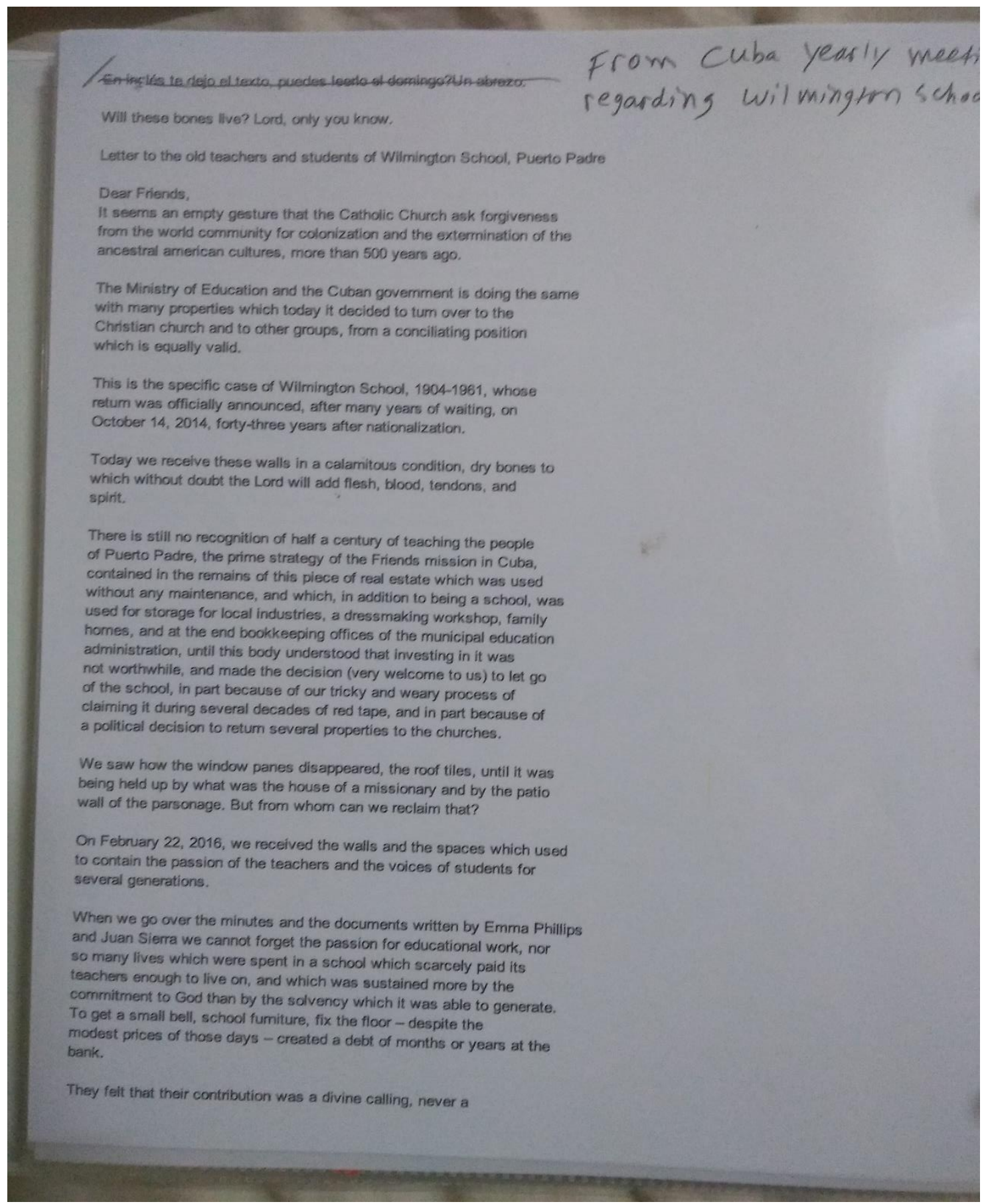

